\title{
Macroflocs from diatoms: in situ photography of particles in Bedford Basin, Nova Scotia
}

\author{
Kate Kranck, T. G. Milligan \\ Physical and Chemical Sciences Branch, Department of Fisheries and Oceans, Bedford Institute of Oceanography, Dartmouth, \\ Nova Scotia, Canada B2Y 4A2
}

\begin{abstract}
Observations of a diatom bloom by in situ photography showed that at the beginning of the bloom the diatoms occurred only as discrete cells and were limited to the surface mixed layer. Below the thermocline, suspended particulate matter concentrations were low and dominated by 200 to $350 \mu \mathrm{m}$ diameter flocs composed mainly of fine-grained detritus and terrestrial sediment. Some time after the beginning of the bloom diatoms started to clump together into aggregate particles, many mm in diameter, composed of a loose network of cells. Flocculation promoted by the high particle concentrations and the development of normal marine surface stickiness caused the diatoms to settle through the thermocline. A progressive increase in the apparent robustness and density of the flocs occurred with depth. The macroflocs could only be detected using the in situ photographs. They did not survive normal Niskin bottle sampling, and Coulter Counter analysis produced particle spectra reflecting only the size of the constituent diatoms and sediment grains. Observations indicate that studies of particle size based on water samples give misleading results and the size of particulate matter in general has been considerably underestimated in past studies based on conventional sampling methods.
\end{abstract}

\section{INTRODUCTION}

Suspended aggregates or flocs of detritus and plankton material are receiving increasing attention in studies of particle fluxes and primary production in the sea. This material, composed mainly of organic matter, has been reported to range from the small microaggregates observed by Riley (1963), to large easily visible macro-aggregates sampled by divers in surface waters (Alldredge 1976, Shanks \& Trent 1979, Silver et al. 1978). Aggregated particles have been variously referred to as marine snow, fecal matter, agglomerates, conglomerates, macroflocs, large amorphous aggregates (LAA) etc., in studies considering their roles in biological, chemical and geological processes (Bishop et al. 1977, Kranck \& Milligan 1980, Syvitski \& Murray 1981, Honjo et al. 1982, 1984, Alldredge 1984). They tend to be defined in terms of differences perceived as resulting from diverse theoretical formational mechanisms even though at the present time very little is known about their origins. Aggregate settling has been evoked to explain the close coupling in time between variation in primary productivity at the surface and planktonic debris arriving at the bottom (Billett et al.
1983, Lampitt 1985) or in subsurface sediment traps (Deuser et al. 1981). Anomalous high production rates in nutrient-poor waters may be based on nutrient regeneration within floc assemblages (Goldman 1984, Silver et al. 1986). Occurrence of live viable diatom cells far below the euphotic zone has been explained by rapid settling of cells included in aggregate material (Platt et al. 1983). Aggregation of diatoms has been described as an integral part of their life history and survival strategy (Smetacek 1985, von Bodungen et al. 1986).

Despite the evidence for the formation of aggregate particles with settling rates greatly exceeding those of the consistuent grains, the cause and mechanics of their formation are not well understood. In this paper we present photographs of aggregated diatoms taken in situ, and discuss their origin and significance relative to particulate fluxes. We believe that the particles are the results of normal floc-forming processes of interparticle collision and physio-chemical and biological cohesion, as demonstrated by Kranck \& Milligan (1980). To emphasize their largely physical origin and to distinguish them from other catagories of organic aggregates they are here referred to as macroflocs. 


\section{MATERIAL AND METHODS}

The size and physical composition of suspended particulate matter throughout the water column were sampled on $3 \mathrm{~d}$ at a $70 \mathrm{~m}$ deep station in the centre of Bedford Basin, Nova Scotia, Canada. Bedford Basin is a small $(3 \times 1.5 \mathrm{~km})$ coastal bay connected with the Atlantic Ocean through Halifax Harbour. It has a maximum depth of $70 \mathrm{~m}$ and is surrounded by rocky shores. Fresh water input varies from $10^{4}$ to $10^{7} \mathrm{~m}^{3} \mathrm{~d}^{-1}$. The bay is relatively productive, partly due to nutrient enrichment from sewage effluent (Platt \& Conover 1971).

Three types of observation were carried out:

(1) In situ photographs of the suspended matter were obtained using a Benthos Plankton Camera (Fig. 1).
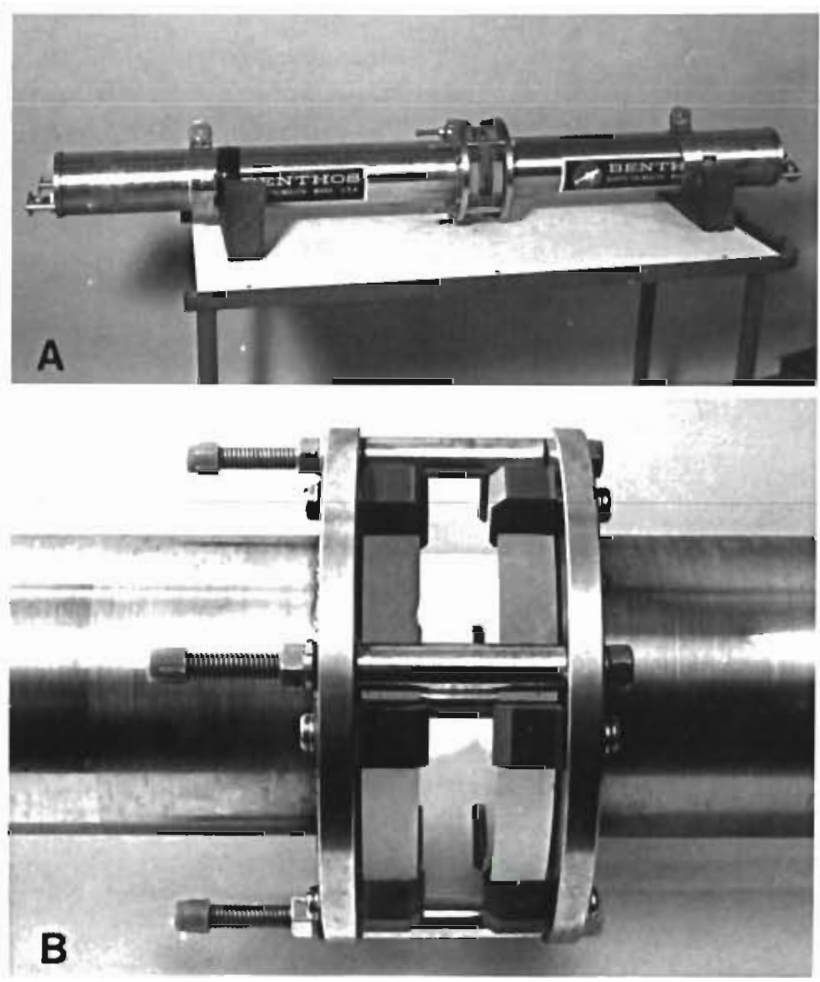

Fig. 1. (A) Benthos Plankton Camera. The camera photographs the water and suspended particles in the open area between a camera package and a light source. (B) Detailed view of sensing area

The camera photographs a $4 \mathrm{~cm}$ thick segment of water, $7.5 \mathrm{~cm}$ in diameter, situated between a focused strobe light source and a $35 \mathrm{~mm}$ camera pack. As it is lowered through the water an exposure is made every $2 \mathrm{~s}$ or every 0.5 to $2.5 \mathrm{~m}$ depending on the lowering rate. Particles greater than $90 \mu \mathrm{m}$ in diameter as well as elongated particles such as diatom chains with one dimension less than this can be detected as silhouette images (Figs. 2 to 5 )

(2) Size distributions of the suspended particulate matter were analyzed using a model TA2 Coulter Counter (Kranck \& Milligan 1979). Fresh seawater obtained with Niskin bottles was counted with 30, 200 and $1000 \mu \mathrm{m}$ orifice tubes to give the size distribution between 0.5 and $400 \mu \mathrm{m}$. The volume concentrations in each logarithmic size class as determined by the Coulter Counter are plotted as log-log size spectra (Fig. 6). Coulter Counter spectra of untreated seawater represent a pseudo-stable distribution intermediate in size between the true in situ particle size and the single constituent particle or grain distribution. Some floc fragments are measured but the larger aggregates are broken up by sample handling and shear in the orifice tubes (Kranck 1984).

(3) Water collected using Niskin bottles was settled in $25 \mathrm{ml}$ settling cylinders overnight and examined with a Zeiss inverted microscope to qualitatively identify composition of the suspended particulate matter.

Chlorophyll concentrations are known from determinations for selected depths on the day before the plankton camera sampling days (B. Irwin pers. comm.).

\section{OBSERVATIONS}

On the first sampling day (11 March 1986) a plankton bloom was in progress and chlorophyll values at this time varied from 33 to $35 \mu \mathrm{g} \mathrm{l}^{-1}$. On the plankton camera photographs, diatoms appeared as elongated needle-like particles which occurred from the surface to the bottom of the mixed layer at $25 \mathrm{~m}$ (Figs. 2 and 5). They were identified microscopically as consisting predominantly of individual chain diatoms (mainly Chaetoceros). Some irregular rounded fragments and incipient aggregations of plankton occurred in the photographs but the overwhelming majority of particles consisted of discrete plankton chains. The Coulter Counter size spectra were dominated by one prominent peak between 25 and $80 \mu \mathrm{m}$, with an order of magnitude lower concentration in the other sizes classes. Below the pycnocline there were no diatoms and the suspended matter visible on the photographs consisted of equidimensional grains and irregular aggregates. Microscopic examination showed particulate matter in the deep water to consist of flocs of fine-grained

Figs. 2 to 4. In situ photographs $(1 \times)$ of water column. Depths: $(A) 1 \mathrm{~m} ;(B) 20 \mathrm{~m}$ (C) $40 \mathrm{~m}_{i}$ (D) $60 \mathrm{~m}$. Fig. 2. $11 \mathrm{March} 1986$. Above the thermocline (about $25 \mathrm{~m}$ ) abundant single diatoms occur and below the thermocline particles consist of miscellaneous aggregates and no diatoms. Fig. 3. 14 March 1986. Above the thermocline some of the diatoms have formed macroflocs many of which have settled into deeper water. Fig. 4. 18 March 1986. Diatoms occur as parts of flocs througout the water colurn 


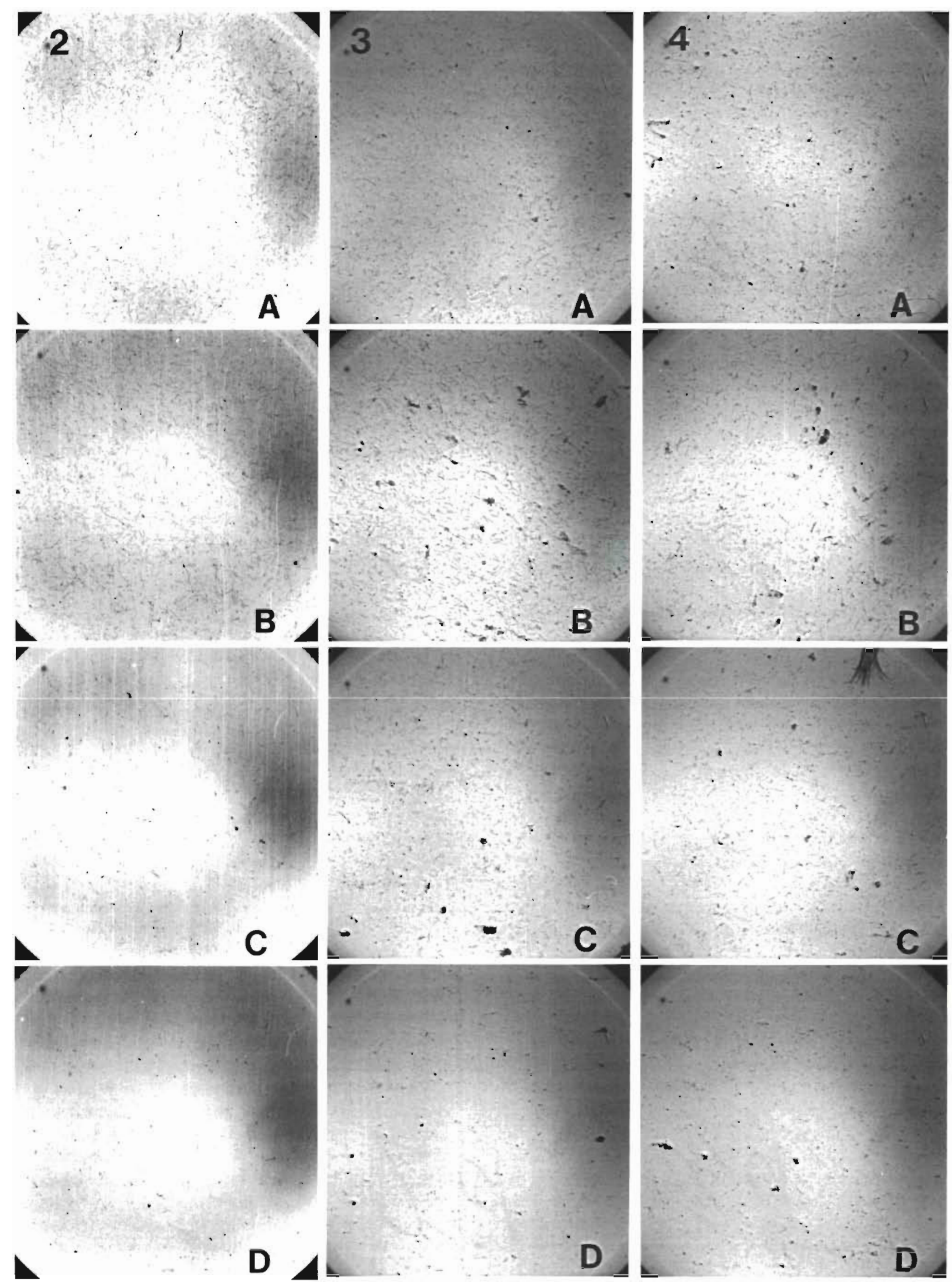



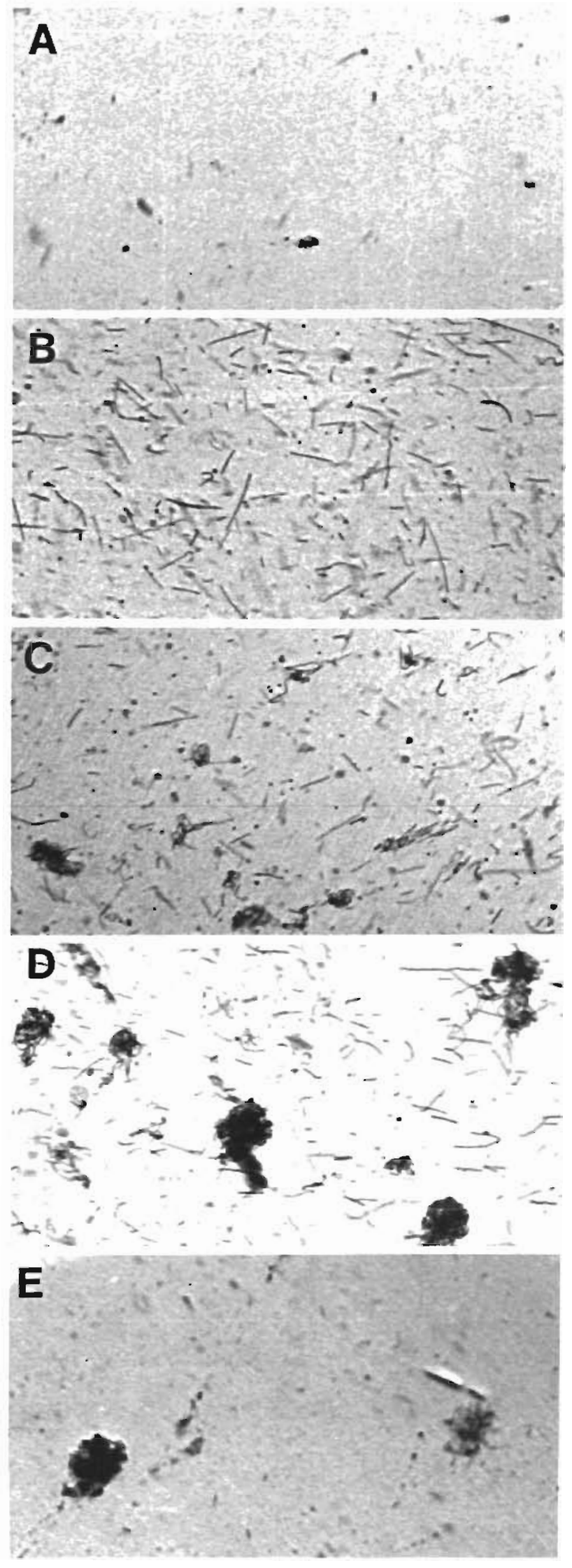

organic detritus and mineral matter and occasional larger single grains. The in situ photographs were dominated by particles greater than $250 \mu \mathrm{m}$. Optically however no detritus larger than $100 \mu \mathrm{m}$ was seen. This discrepancy, interpreted as floc break-up in sampling and analysis, was confirmed by the Coulter Counter. which produced relatively flat and featureless size spectra with no evidence of concentrations of particles with diameters above $100 \mu \mathrm{m}$.

Three d later (14 March 1986) chlorophyll values ranged from 30 to $32 \mu \mathrm{g} \mathrm{I}^{-1}$. The individual diatoms chains were still present in the surface waters but also present, as shown in the photographs (Figs. 3 and 5), were flocs composed of clusters of diatom chains. In the smaller flocs individual plankton could still be distinguished but in the larger aggregates the phytoplankton composition was apparent only from the fibrous internal structure and occasional phytoplankton-like threads protruding from the edge. The flocs ranged in size between 200 and $500 \mu \mathrm{m}$ and were not present in the water samples examined microscopically, nor did they register in the Coulter Counter analysis (Fig. 6). The same phytoplankton peak at 25 to $80 \mu \mathrm{m}$ was present as $3 \mathrm{~d}$ earlier and in the surface samples a peak, believed to originate from sediment in a thin layer of fresh water due to recent heavy rains, was also found. In the subsurface layer no single phytoplankton chains occurred in the photographs, but flocks identical to those in the surface later were abundant, becoming slightly less abundant towards the bottom. The flocculated state of the phytoplankton was apparent only from the plankton camera photographs, whereas microscope examination and Coulter analysis showed discrete phytoplankton chains and a 35 to $80 \mu \mathrm{m}$ modal peak respectively.

On the third sampling day (18 March 1986) chlorophyll concentrations had decreased (9 to $21 \mathrm{ug}$ $1^{-1}$ as measured the day before). The particle distribution (Fig. 4) and stratification (Fig. 6) were similar to those of the second day except that there was more sediment in the surface layer and the plankton peak in the deeper layer was more prominent. A significant feature in the distribution was the increase in density of the aggregates with depth, changing from loose open networks near the surface to solid particles near the bottom (Fig. 5). Also noteworthy were the noticeably

Fig. 5. Details of in situ photographs (4x). (A) Miscellaneous detritus below thermocline before sinking of diatom flocs (11 Mar 1986; $51 \mathrm{~m}$ ). (B to E) Progressive stages in the development of diatom macroflocs. (B) Single diatom cells (11 Mar $1986 ; 1 \mathrm{~m}$ ). [C and D] Mixture of single diatom cells and flocculated cells (14 Mar 1986; $7 \mathrm{~m}$ and $28 \mathrm{~m}$ ). (E) Compact flocs of diatoms which have settled into near-bottom waters (18 Mar 1986; $68 \mathrm{~m}$ ) 


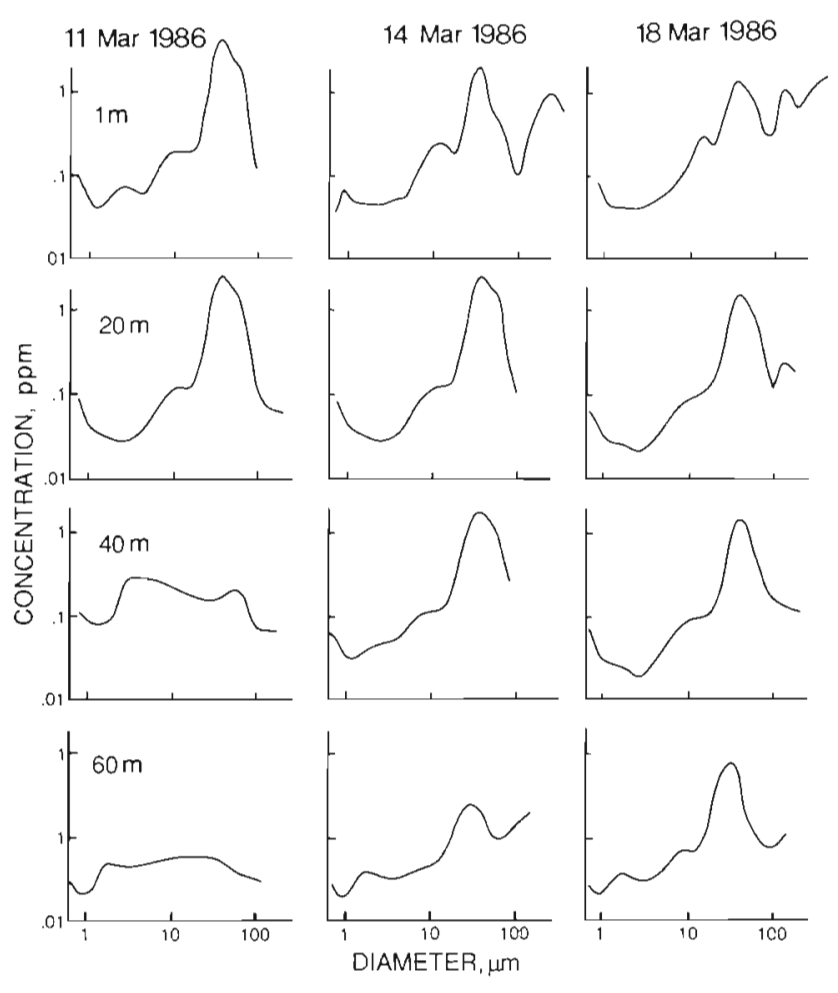

Fig. 6. Particle size spectra of suspended particulate matter in seawater samples measured using a Coulter Counter Size distributions show volume/volume concentrations (ppm) in logarithmically equal size classes from 4 depths on 3 dates

fewer and in some cases completely absent phytoplankton flocs when the carnera was stopped in the water every $10 \mathrm{~m}$ in order to obtain extra exposures.

\section{DISCUSSION}

The use of a camera to photograph plankton and particulate matter without removing it from the natural environment shows the presence of aggregates or flocs of phytoplankton. Monitoring a diatom bloom over $7 \mathrm{~d}$ indicates that aggregate formation is a time-dependent process during which the diatom population progresses from a state of all single chains to one containing single chains and clusters of 2 or several chains and finally a state in which most of the diatoms are tied up in solidlooking rounded bodies in which individual chains cannot be distinguished. The single chains occurred only above the pycnocline while the flocs apparently are able to settle through the pycnocline to the bottom.

The occurrence of aggregates or flocs containing plankton cells is well documented from numerous descriptions from coastal and open ocean environments (Honjo et al. 1984, Cadée 1985). Their roles in transporting matter to the bottom have been discussed (Deuser et al. 1981, Fellows et al. 1981, Honjo et al.
1982, Lampitt 1985, Smetacek 1985). They are known to form micro-environments which concentrate chemicals and organisms relative to the total environment, and support a significant planktonic population adapted to exist in association with suspended detritus (Goldman 1984a, Beers et al. 1986, Silver et al. 1986, Alldredge \& Cohen 1987). The question of how flocculated particles are formed and their overall life histories however has received relatively little attention and most workers are content to emphasize that they are of 'biological origin'. Whether this means that organisms do the clumping together of the constituent material through processes such as fecal pellet formation (Honjo et al. 1982) or building of extracellular feeding structures (Alldredge 1976), or simply means that the bulk of the material forming the aggregates is of organic origin, is not clear.

In the Bedford Basin photographs, the loose structure and relatively healthy appearance of the individual cells in the bundles of chains when first formed point to physical factors as the formative process. Kranck \& Milligan (1981) have demonstrated that any particle suspension in a saltwater medium tends to floc and acquire settling rates sufficient to settle out, irrespective of turbulence levels or the speed of upwarddirected flow. This was seen as following from the cohesive character of surfaces and of collisions of grains due to shear and differential settling. It results in the formation of flocs each of which contained a representative proportion of the suspended matter present in the suspension. If flocculation is a universal process in marine suspensions, why were the diatoms not flocculated on the first sampling day despite the very high particle concentration, and what governs the progress of flocculation in a suspension of living particles? Flocculation and rapid settling in an aging bloom is in accord with many observations that higher settling rates accompany senescence (Smayda 1970). This stage may simply represent the onset of normal particle surface conditions as opposed to the ability of the healthy young phytoplankters to control their surface chemistry so as to remain non-cohesive. For example control of surface bacteria by excretion of antibiotics may be a possible mechanism to counteract flocculation (Wangersky 1978). In this case flocculation is limited by the rate at which the cohesive surface is developed. Flocculation is also controlled by the rate of inter-particle collisions, a function of micro-turbulence and total concentration. This is in accord with Cadée's (1985) observation of macroaggregates of coccolithophorids which formed just after maximum cell abundance. Subsequent to the initiation of a bloom by e. $g$. injection of nutrients from below, flocculation and settling may be a principal factor controlling the lifetime of the phytoplankton bloom. Besides grazing, 
floc formation may be the only removal process of phytoplankton from the surface waters. The lack of diatoms in the deeper waters on the first day when no flocs had yet formed and the presence there of diatoms as part of flocs 2 d later indicates that diatoms despite their relatively high still-water settling rate did not settle through the pycnocline as single chains. Turbulence structure presumably prevents the particles from penetrating this interface, but the exact suspension mechanism is not clear.

The increase in density with depth as indicated by the darker, more solid appearance of the large particles below the thermocline should result in a concomitant increase in settling rate. Below the thermocline some scavenging of additional material onto flocs may occur, but since the diatoms originate at the surface, settling flux should be fairly constant with depth. If $F=W C$ where $F$ is flux and $W$ is average settling rate, the particle concentration, $C$, below the pycnocline should decrease with depth as particles spend less and less time at any given depth. This is in agreement with the observed decrease in concentration with depth in Bedford Basin. Similar 'shrinkage effects' may contribute towards the commonly observed decrease in concentration below the mixed layer in water columns in general.

Two reasons for the lack of plankton in the photographs exposed when the camera stopped moving through the water can be proposed, namely break-up of flocs in the vicinity of the camera and failure of the flocs to settle past the imaging area of the camera. The extremely fragile nature of macro-flocs was demonstrated in laboratory experiments during which flocs formed in response to a flow condition, but immediately flow conditions were altered the flocs tended to shatter (Kranck \& Milligan 1980). It is not improbable that the turbulent structure around the camera suspended from an anchored vessel would homogenize the particle structure inside and around the instrument.

A significant factor in the settling of diatom flocs in Bedford Basin may have been the influx of sedimentrich water just before the last sampling day. Heavier silicate grains, because of their presence in the same suspension as the diatoms, would be expected to flocculate together and act as sinkers for the diatom flocs.

The observations made in this study were possible only through the use of in situ photography. Studied with conventional methods, the occurrence of diatoms below the thermocline would be interpreted as the settling of single grains at the end of a bloom. The Coulter Counter spectra and microscopic examination on the first day of sampling give the impression that the particulate matter below the thermocline $(35 \mathrm{~m})$ consisted of relatively straight spectra with maximum par- ticle sizes below 90 um (Fig. 6), as opposed to dominance of the size distribution by 250 to $500 \mu \mathrm{m}$ flocs (Fig. 4) indicated by the photographs. The apparent scarcity of $<250 \mu \mathrm{m}$ particles suggests that the flat distributions measured by the Coulter Counter are a product of floc break-up as observed previously in studies of sediment-rich coastal environments (Kranck 1984, Eisma 1986). Flat spectra have been commonly measured in the oceans (e.g. Sheldon et al. 1972) and it is unfortunate that the lack of resolution of small particles by the plankton camera limits further verification of this important point.

\section{SUMMARY AND CONCLUSIONS}

Based on in situ photography, it is shown that diatoms of a spring bloom were found only above the thermocline when they occurred as individual. single cell particles. Some time after the start of the bloom possibly related to the development of normal marine surface stickiness due to physio-chemical and biological factors such as surface charges, adsorption effects, bacterial slime etc., diatoms flocculate into aggregate particles with sufficiently high settling rates to penetrate through the thermocline.

Observations of water samples collected simultaneously with the photographic observations gave misleading impressions of the particle grain sizes. Both the diatom-flocs and smaller flocs of organic and inorganic detritus were shattered in the sampling process and the overall grain size was considerably reduced.

The present study demonstrates a need for observations of in situ size of suspended particulate matter. The work also points to a need for better understanding of particle settling mechanics, especially the effect of density interfaces on fluxes of suspended particulate matter

Acknowledgements. We thank P. J. Wangersky and T Platt for critical review of the manuscript and B. Irwin for assistance in the field. The photographs were reproduced by $\mathrm{H}$. Wiele.

\section{LITERATURE CITED}

Alldredge, A. L. (1976). Discarded appendicularian houses as food, surface habitats, and particulate organic matter in the planktonic environments. Limnol. Oceanogr. $21 ; 14-23$

Alldredge, A. L. (1984). Macroscopic organic aggregates (marine snow) In: Global Ocean Flux Study: Proceedings of Workshop, Sept. 10-14, 1984, National Academy of Sciences, Woods Hole Study Centre, Woods Hole, Mass., National Research Council. National Academy Press, Washington, D. C.

Alldredge, A. L., Cohen, Y, (1987). Can microscale chemical patches persist in the sea? Microelectrode study of marine snow, fecal pellets. Science 235: 689-691

Beers, J. R., Trent, J. D., Reid, F. M. H., Shanks, A. L. (1986) 
Macroaggregates and their phytoplanktonic components in the Southern California Bight. J. Plankton Res. 8: 475-487

Billett, D. S. M., Lampitt, R. S., Rice, A. L., Mantoura, R. F. C. (1983). Seasonal sedimentation of phytoplankton to the deep-sea benthos. Nature, Lond. 302: 520-523

Bishop, J. K. B., Edmonds, J. M., Kellon, D. R., Bacon, M. P.. Silker, W B. (1977). The chemistry, biology and vertical flux of particulate matter from the upper $400 \mathrm{~m}$ of the equatorial Atlantic Ocean. Deep Sea Res. 24: 511-548

Cadée, G. C. (1985). Macroaggregates of Emiliana huxleyi in sediment traps, Mar. Ecol. Prog. Ser. 24: 193-196

Deuser, W. G., Ross, E. H., Anderson, R. F. (1981). Seasonality in the supply of sediment to the deep Sargasso Sea and implications for the rapid transfer of matter to the deep ocean. Deep Sea Res. 28: 495-505

Eisma, D. (1986). Flocculation and de-flocculation of suspended matter in estuaries. Neth. J. Sea Res. 20: 183:199

Fellows, D. A., Karl, D. M., Knauer, G. A. (1981). Large particle fluxes and the vertical transport of living carbon in the upper $1500 \mathrm{~m}$ of the northeast Pacific Ocean. Deep Sea Res. 28A: 921-936

Goldman, J. C. (1984a). Ocean nutrient cycles. In: Fasham, M. J. R. (ed.) Flows of energy and materials in marine ecosystems, theory and practice. Plenum Press, New York, p. $137-169$

Goldman, J. C. (1984b). Conceptual role for microaggregates in pelagic waters. Bull mar. Sci. 35: 462-476

Honjo, S., Doherty, K. W., Agrawal, Y C., Aspers, V. L. (1984) Direct optical assessment of large amorphous aggregates (marine snow) in the deep ocean. Deep Sea Res. 31:67-76

Honjo, S., Manganini, S. J., Cole, J. J. (1982). Sedimentation of biogenetic matter in the deep ocean. Deep Sea Res. 29. $609-625$

Kranck, K. (1984). The role of flocculation in the filtering of particulate matter in estuaries. In: Kennedy, V. S. (ed.) The estuary as a filter. Academic Press, New York, p. 159-175

Kranck, K., Milligan, T (1979). The use of the Coulter Counter in studies of particle-size distributions ir dquatic environments. Bedford Institute Report Series BI-R-79-7, Dartmouth

Kranck, K., Milligan, T (1980). Macroflocs: production of marine snow in the laboratory. Mar. Ecol. Prog. Ser. 3: 19-24
Lampitt, R. S. (1985). Evidence for the seasonal deposition of detritus to the deep-sea floor and its subsequent resuspension. Deep Sea Res. 8: 885-897

Platt, T., Conover, R. J. (1971). Variability and its effect on the $24 \mathrm{~h}$ chlorophyll budget of a small marine basin. Mar. Biol. 10: $53-65$

Platt, T., Subba Rao, D. V., Smith, J. C., Li, W. K., Irwin, B. Horne, E. P. W., Sameoto, D. D. (1983). Photosyntheticallycompetent phytoplankton from the apothic zone of the deep ocean. Mar Ecol. Prog. Ser. 10: 105-110

Riley, G. A. (1963). Organic aggregates in seawater and the dynamics of their formation and utilization. Limnol Oceanogr. 8: 372-381

Shanks, A. L., Trent, J. D. (1979) Marine snow: microscale nutrient patches. Limnol Oceanogr. 24: 850-854

Sheldon, R. W., Prakash, A., Sutcliffe, W. H., (1972). The size distribution of particles in the ocean. Limnol. Oceanogr. 17: $327-340$

Silver, M. W., Gowing, M. M., Davoll, P. J. (1986). The association of photosynthetic picoplankton and ultraplankton with pelagic detritus through the water column $(0-2000$ m). In: Platt, T., Li, W. K. (eds.) Photosynthetic picoplankton. Can. Bull. Fish. aquat. Sci. 214: 311-341

Silver, M. W., Shanks, A. L., Trent, J. D. (1978). Marine snow: microplankton habitat and source of small scale patchiness in pelagic populations. Science 201: 371-373

Smayda, T. J. (1970). The suspension and sinking of phytoplankton in the sea. Oceanogr. mar. Biol. A. Rev. 8: $353-414$

Smetacek, V S. (1985). Role of sinking in diatom life-history cycles: ecological, evolutionary and geological significance. Mar. Biol. 84: 239-251

Syvitski, J. P. M., Murray, J. W. (1981). Particle interaction in fjord suspended sediment. Mar. Geol. 39: 215-242

Von Bodungen, B., Smetacek, V. S., Tilzer, M. M., Zeitzschel, B. (1986). Primary production and sedimentation during spring in the Antarcitic Peninsula region. Deep Sea Res. 33: $177-194$

Wangersky, P. J. (1978). Production of dissolved organic matter In: Kinne. O. (ed.) Marine ecology, Vol. IV, Dynamics. John Wiley \& Sons, Chichester, p. 115-220 